\title{
A Tale of Two Dams: The Impact of Reservoir Management on Rural Depopulation in Central Spain
}

\author{
Beatriz Larraz $^{1}$ (D) Enrique San-Martin ${ }^{2}$ (D)
}

Received: 25 March 2021 / Accepted: 12 August 2021 /Published online: 12 October 2021

(c) The Author(s) 2021

\begin{abstract}
In rural areas, depopulation is mainly due to a lack of economic and employment opportunities. In this context, the reservoirs already built can be a source of socioeconomic development based on tourism and outdoor leisure activities. The condition for this development to materialize is that reservoir management considers these activities. In Central Spain, a process of rural depopulation has been generated in the municipalities around the reservoirs at the Upper Tagus River, as water management allows water transfers from the Tagus to the Segura River without taking into account regulations that prioritize and protect donor basin users. Through the comparison of reservoir water management and demographic data of two rural areas close to the reservoirs, this article reveals the direct relationship between reservoir management that enables recreational uses with its consequent socioeconomic development and the maintenance of the population in the territory. Consequently, reservoir water management based on the socioeconomic development of reservoir banks is necessary and a priority over transfers to another basin.
\end{abstract}

Keywords Demographic challenge $\cdot$ Depopulation $\cdot$ Hydrological planning $\cdot$ Reservoir management $\cdot$ Tagus-Segura water transfer

\section{Introduction}

The phenomenon of the depopulation of rural areas is widespread across Europe, although it has been particularly intense in southern Europe (Collantes et al. 2014; Moreno 2018). Spain showed a significant rural exodus to cities between 1950 and 1980 (García Docampo 2016), and this movement was driven by the lack of economic opportunities offered by rural areas compared to the better standard of living available in cities (Del Molino 2016; Cerdá 2017; Pinilla and Saez 2017). Even today, this thwarted aspiration of being able to earn a living in rural areas is the reason why young people leave for cities (Zoido and Arroyo 2003; Collantes and Pinilla 2011). Consequently,

Beatriz Larraz

Beatriz.larraz@uclm.es

1 Universidad de Castilla-La Mancha, Cobertizo de San Pedro Mártir s/n, 45071 Toledo, Spain

2 Universidad Nacional de Educación a Distancia, Paseo de la Senda del Rey, 11, 28040 Madrid, Spain 
these rural areas tend to move towards an ageing demographic dynamic, with low birth rates, a lack of services and attention from authorities and, ultimately, lower material living standards (Burillo-Mozota 2011; Burillo et al. 2013; Pinilla and Saez 2017).

Rural areas, however, offer natural spaces around which leisure activities and active tourism can be used to trigger the first steps of an economic development process. Natural lakes and, in some cases, reservoirs have long been a prominent place for leisure and tourism activities (Yusof et al. 2019), and many countries have promoted them as tourist destinations (Hall and Härkönen 2006). Tikkanen (2003) states that lakes are commonly used for ecotourism, recreational tourism, sports and other activities, usually attracting millions of people and contributing significantly to the socioeconomic development of a region. Otiang'a-Owiti and Oswe (2007) also believe that lakes are an important engine of socioeconomic development. According to Duda-Gromada et al. (2010), in arid or semiarid areas with few or no natural lakes, an artificial reservoir can be an important driver of tourism.

Many of the reservoirs that were built in Spain in the 1950s flooded entire villages and their best farmland at a time when agriculture was the main way of life in rural areas. In some cases, particularly in regions close to large cities, these reservoirs provided an opportunity for economic development based on the tourism sector. Some navigable reservoirs close to Madrid, the capital of Spain, such as the Entrepeñas and Buendía (E\&B) Reservoirs at the Tagus River headwaters or the San Juan Reservoir at the Alberche River headwaters, were promoted as inland seas, an attractive alternative to a much longer trip to the coast from Central Spain. In less than two hours, the people of Madrid could enjoy tourism, leisure and recreational opportunities offered by the reservoirs, providing new economic possibilities for the local economies.

The E\&B reservoirs were located in a region characterized by great scenic beauty and an important cultural and natural heritage. Moreover, the existence of a large water surface area of more than 11,400 hectares, not far from the Madrid metropolitan region, gave this territory enormous potential for development at a time when tourism had begun to accelerate in Spain. During the 1960s, 1970s and even 1980s, second residence developments, hotels, restaurants, leisure facilities, and marinas were built, particularly in the surrounding area of the Entrepeñas Reservoir and, to a lesser extent, in that of Buendía. The new life brought about by the reservoir seemed to work, and the area known as "Sea of Castille" (Mar de Castilla)" and its beaches became a popular place for summer leisure.

While this new economic model developed unhindered for the San Juan Reservoir, the establishment of the Tagus-Segura Water Transfer system (Tagus-Segura Transfer, TST, hereinafter) in 1981 would decisively truncate it in the municipalities of E\&B. The combination of a sharp decrease in water inflow to the E\&B reservoirs (-50\%) since the beginning of the 1980s compared to the data used in the TST construction project and, above all, a reservoir management strategy that has prioritized the water transfer to Southeast Spain for political-economic reasons, has resulted in the area's depopulation and socioeconomic decline (San Martín et al. 2020). In addition, reservoir management has been carried out in a way that completely ignores the needs of the municipalities around the reservoir and the legal priority of all water uses in the donor basin, including recreational activities. The drastic decrease in the water surface in absolute terms and the extreme variability because of the management of the water transfer system means entrepreneurs and businesses have lost confidence. The result has been a continuous and generalized depopulation and socioeconomic decline of these municipalities, which is a consequence of the lack of economic expectations. 
This article focuses on the loss of population, the most visible outcome of the poor economic prospects in the $\mathrm{E} \& \mathrm{~B}$ region. Its aim is to show the direct relationship that exists between the depopulation of the municipalities around $E \& B$, despite its potential as a tourist attraction, and the way the reservoirs have been managed. For this, a comparison was made between the municipalities of $\mathrm{E} \& \mathrm{~B}$, the neighbouring rural municipalities in the same provinces, where there is less or no influx at all from the reservoirs and, in particular, with municipalities near the San Juan Reservoir. In the latter reservoir, also not far from Madrid, considerable tourism development has occurred as a result of support from reservoir management.

By comparing the demographic evolution of the municipalities of the E\&B Reservoirs and those of the San Juan Reservoir, with the management of these two reservoirs carried out by the relevant authorities, the analysis intended to show that the depopulation situation experienced by the former compared to the latter was due to the missed opportunity for economic development based on tourism and recreational activities.

The rest of the paper is structured as follows. Section 2 describes the methodology used in the analysis and the novelty of this research. Section 3 reviews the recent literature about the TST and its impacts, while Sect. 4 briefly describes the case study areas. Section 5 examines the differences in water management that have been carried out in both reservoirs. Section 6 analyses the demography of the areas, and finally, Sect. 7 presents the conclusions.

\section{Methodology}

To make the figures and demographic analysis clearer, a double comparative analysis of the evolution and demographic profile of the E\&B municipalities was carried out. First, their demographic evolution was compared with the evolution of the rest of the rural municipalities of the provinces of Cuenca and Guadalajara to establish whether the E\&B Reservoirs have been a differentiating element from a demographic perspective. This process was then repeated for the municipalities of the San Juan Reservoir in Madrid to identify any demographic evolution because it is a tourist destination for the large population of Madrid. The population analysis was carried out using the ten-yearly historical data from 1900 to 2011 of the population censuses ${ }^{1}$ available at the National Institute of Statistics (INE). In addition, the annual data from the municipal register ${ }^{2}$ were analysed from 1996, and these data are also available from the aforementioned institute (INE 2020).

Particular attention is given to population variations in the periods between the completion of E\&B at the end of the 1950s and when the TST started operating (1981) and after that moment to the present (2020). This approach was used to identify the possible impact that the TST and the resulting fluctuations on the water surface and levels have had on tourism and leisure activities and socioeconomic aspects and, consequently, on the demographic evolution of the municipalities surrounding both reservoirs.

\footnotetext{
1 The Population and Housing Censuses are statistical operations carried out every ten years. This research gives information on the characteristics of the population, households, buildings and dwellings (INE 2020).

2 The Municipal Register is an administrative registry of the residents listed in the municipality. Its compilation, maintenance, reviews and custody correspond to the respective City Councils who must send the INE the monthly data variations that occur in their municipal registers (INE 2020).
} 
A comparison with the demographic evolution of other rural municipalities in the territory is necessary since the depopulation processes observed in the municipalities analysed are also characteristic of other rural areas. This study aimed to determine whether the trends observed in the municipalities adjacent to the reservoirs were different from those of other comparable rural municipalities. To identify similar municipalities in the territory, the concept of rural Cuenca and rural Guadalajara was used, which included municipalities with fewer than 5000 inhabitants (MARM 2009) in each of these provinces.

The novelty of this article is that it clearly links reservoir management with population dynamics. This can be done in this case study, as both places are small from an economic perspective, and the reservoirs are the main economic asset. In addition, the analysis shows that, in both cases, tourism and leisure activities based on reservoirs were a real economic alternative to agricultural development that could help to maintain the rural population. The authors did not find records of a similar analysis.

In addition, the case of the municipalities of the E\&B Reservoirs may be unique, since it is very unusual that in the same geographical area, in little more than a century, there have been three models of economic development: first, agrarian; second, tourist and recreational; and, finally, a development model without leading economic activities. It must be kept in mind that these changes were abrupt and externally imposed.

\section{The TST and the Socioeconomic Impacts}

The TST is by far the largest, longest, most complex and controversial interbasin water transfer system in Spain. The TST was planned to transfer $1.000 \mathrm{hm}^{3}$ from the E\&B Reservoirs in the headwaters of the Tagus Basin to the Segura Basin in Southeast Spain. As the amount of resources at the Tagus headwaters was less than planned, in the first phase, only a maximum annual transfer of $600 \mathrm{hm}^{3}$ was allowed, although the average annual transfer was approximately 300-350 $\mathrm{hm}^{3}$ (Hernandez-Mora and del Moral 2015; Rey et al. 2016).

In the last decade, publications on the transfer in international scientific journals and books have increased significantly due to its multidimensional problems. Pittock et al. (2009) assessed several water transfer projects, including the TST, to conclude that, due to its potential negative consequences, water transfers should be the last option used to solve water scarcity problems. Sharing the same reasoning, San Martín et al. (2020) explained the negative environmental and socioeconomic impacts that the TST has caused in the Tagus Basin. In contrast, Molina and Melgarejo (2016) and Morote et al. (2017) supported the TST based on the socioeconomic development of the recipient basin. Although they recognized the priority of the donor basin or the need to preserve the environmental values, they failed to mention that both principles have always been in the letter and the spirit of the law, but regarding the TST, they were completely ignored (De Lucas 2019; Gallego 2019). Lorenzo-Lacruz et al. (2010) and Lobanova et al. (2017) analysed climate change impacts at Tagus headwaters, where the transfer starts, from a hydrological perspective. Both agreed that the traditional management of water resources could not be maintained as before; therefore, new strategies were needed to balance economic, social and ecological benefits. Finally, Hernandez-Mora and del Moral (2015) and Rey et al. (2016) addressed the economics of water markets through the TST. While the latter estimated that water markets with option contracts could improve global efficiency and generate net economic benefits, the former, analysing several real transactions, showed that this net economic gain occurred at the expense of Spanish taxpayers. 

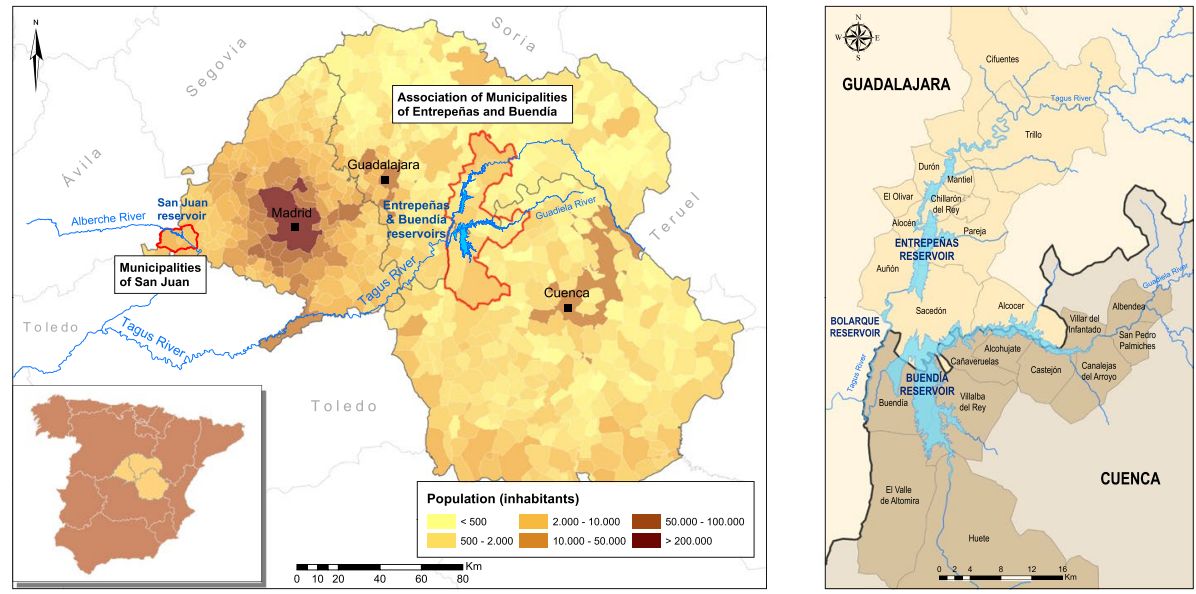

Fig. 1 Location of the Entrepeñas, Buendía and San Juan Reservoirs (left) and the E\&B municipalities (right). Source: compiled by the authors (@Mario Ballesteros)

Regarding the socioeconomic dimension, the negative consequences of the TST for the donor basin are neglected most of the time, as they had been eclipsed by the economic development of the Segura Basin. Lobanova et al. (2017: 446) provided a good example of this problem: they suggested it was best "to assess the socioeconomic impacts in the Segura River basin derived from a much reduced capacity of the Tagus to provide water" but forgot to estimate the negative socioeconomic impacts caused by the TST in the Tagus Basin. Although some works mentioned these negative impacts (Hernández-Mora 2013; San Martin et al. 2020), the novelty of this article from a hydrological perspective is to quantify some of them through the analysis of population dynamics, the only variable with enough detailed temporal and spatial data to carry out this analysis.

\section{The Municipalities of Entrepeñas and Buendía and of the San Juan Reservoir}

The E\&B Reservoirs were built in 1956 and 1959 at the Tagus River headwaters, located $120 \mathrm{~km}$ ( $1.30 \mathrm{~h}$ by car) east of Madrid. With a combined capacity of $2518 \mathrm{hm}^{3}$, they represent the largest regulated water system at the headwaters of a river on the Iberian Peninsula. The San Juan Reservoir was built in 1954 on a tributary of the Tagus River, the Alberche, $84 \mathrm{~km}$ ( $1 \mathrm{~h}$ by car) west of Madrid, with a storage capacity of $138 \mathrm{hm}^{3}$ (see Fig. 1, left). Despite the clear difference in capacity, both systems are comparable: both are multipurpose projects (irrigation, industry, human consumption and hydroelectric production) and are similar from a sociodemographic perspective due to the distance and impact that the nearby population of Madrid, with more than 6 million inhabitants, has had on both areas. Both bodies of water and their ecological environment have been tourist attractions in Spain since the 1960s, although since the 1980s, with the impact of the diversion of water from E\&B to Southeast Spain through the TST, their trajectories have been very different. 
The 22 municipalities bordering the E\&B Reservoirs are located in the Spanish provinces of Cuenca and Guadalajara (see Fig. 1, right) with a population density of 6.3 inhabitants $/ \mathrm{km}^{2}$. This area is considered a very sparsely populated area (Böhme et al. 2009). The San Juan Reservoir is located mainly within the municipalities of San Martín de Valdeiglesias and Pelayos de la Presa in the province of Madrid. Both municipalities are part of the Sierra Oeste Madrid region, an area that is considered isolated, with population concentrations much lower than those of the larger towns in the Madrid area but higher than those of similar mountain areas (García and Navarro 2002).

Both areas have national and regional recognition as protected areas, which highlights their natural value, making the reservoirs important tourist attractions for recreational use.

\section{Management of the Entrepeñas and Buendía Reservoirs and Management of the San Juan Reservoir: Different Priorities and Results}

\subsection{The reservoirs of Entrepeñas and Buendía}

The reasons for building the E\&B Reservoirs, as set out in the technical project, were based exclusively on exploiting the Tagus Basin for hydroelectric operations and irrigation development (Jiménez Aparicio 1947). With the construction of the reservoirs, the plains and most fertile lands of the municipalities where they would be located were flooded (Flores 2004) and, from then on (late 1950s and early 1960s), the process of depopulation began in these municipalities. Migratory phenomena from the countryside to the city and the loss of population in rural municipalities were not exclusive to this area but, as discussed in more detail in Sect. 6, it was a phenomenon that was exacerbated when the TST started in the 1980s.

In exchange for the abandonment of agriculture, the construction of the reservoirs allowed for the development of tourism linked to the recreational uses of the reservoirs, particularly around Entrepeñas, where the main urban developments were located. However, the onset of water transfer by the TST would mean a substantial change in the landscape and socioeconomic reality of the territory because of the management of the reservoirs imposed by water transfer.

In 1968, construction of the TST was authorized, and in 1978, it began operating, first in the testing phase and, starting in 1981, in the operational phase (CHT 2015). The legislation established that only surplus water could be transferred once all the needs and uses of the Tagus Basin had been satisfied, without their "development possibilities" being affected or diminished. Law 21/1971 (BOE 1971) established that "users of the Tagus Basin should not see their development possibilities diminished due to the scarcity of hydraulic resources, as a consequence of the Transfer" and that only "excess regulated flows coming from the Tagus River" would be transferred (preamble and article 1 of Law 21/1971). Law 52/1980 (BOE 1980) also reiterated the obligation to adopt pertinent measures and adequate regulation so that "the waters that are transferred are, at all times, a surplus of the Tagus Basin" and that "the definition of surpluses will be determined in the Tagus Basin Hydrological Plan", for which purpose all current and potential uses "resulting from the natural development of the Tagus Basin provinces" must be considered (ninth additional provision of Law 52/1980). It should be noted that Spanish River Basin Management Plans (RBMPs) set the order of allocation priority 
to grant water concessions within a river basin. Thus, in the Tagus RBMP (the Tagus Basin Hydrological Plan), the domestic water supply and irrigation have priority over industrial and recreational uses. However, internal uses of the river basin itself, whatever they may be, have priority over external water demands. Therefore, recreational uses of the Tagus Basin itself are a priority and must be guaranteed against any possible transfer, regardless of the destination of the transferred water (urban supply, irrigation, etc.), assuring the recreational uses of the E\&B Reservoirs.

In 1998, the Tagus RBMP (CHT 1998), which was approved by Royal Decree 1664/1998, established that transfers could not be carried out when the joint E\&B reserves were below $240 \mathrm{hm}^{3}$ (less than $10 \%$ of the reservoir capacity); thus, any higher volume was considered a surplus up to the maximum transferable to the Segura Basin, which was 600 $\mathrm{hm}^{3}$. In theory, this lower limit should guarantee all the needs of the donor basin, including recreational uses in headwater reservoirs that had a priority above any water transfer outside the basin. However, this limit did not consider the volumes necessary for the recreational uses of E\&B. Below this limit, no transfers to the Segura Basin could be approved, but $240 \mathrm{hm}^{3}$ could be released from the reservoirs to meet Tagus Basin water needs (RD $773 / 2014$-BOE 2014-). Drought could result in the emptying of both reservoirs, reaching a "dead reservoir" level of approximately $118 \mathrm{hm}^{3}$ (Cabezas 2013). In fact, a reservoir level as low as $240 \mathrm{hm}^{2}$, which barely accounts for $10 \%$ of the total capacity of both reservoirs, can hardly guarantee the recreational uses associated with them. This occurred despite the fact that article 12.2 of the National Hydrological Plan (Law 10/2001 -BOE 2001-) established the principle of guaranteeing all current and future demands of all uses of the donor basin, including environmental flows, without limiting the socioeconomic development of the basin because of water transfers.

Subsequently, in 2013, the Tagus Memorandum was signed (additional provisions in Law 21/2013 -BOE 2013- and in Law 21/2015 -BOE 2015-), officially overriding the Tagus RBMP and setting an increase in the minimum non-transferable volume to 400 $\mathrm{hm}^{3}$ in E\&B to guarantee the local supply of Madrid and Castilla-La Mancha in periods of drought. Although the elevation of the minimum non-transferable amount from 240 to $400 \mathrm{hm}^{3}$ was presented as a success for the Tagus Basin and especially for the bordering municipalities of $E \& B$, the increase was modest and did not improve the outlook for the tourism sector. Additionally, as was the case with the previous limit, an amount of $400 \mathrm{hm}^{3}$ (15.8\% reservoir fill) cannot guarantee recreational uses or the stabilization of the stored volume at this level.

As shown in Fig. 2, the E\&B combined levels of 240 (summer 2017, images e \& f) or $400 \mathrm{hm}^{3}$ (summer 2015, images c \& d), the non-transferable limits approved in 1998 and 2013, respectively, do not present significant differences in terms of the water surface area. Therefore, these volumes of water do not allow the normal development of water sports or lodging and restaurant businesses in E\&B since, from both a scenic perspective (Fig. 2, images $d \&$ e) and in terms of navigability conditions (Fig. 2, images $\mathrm{c} \& \mathrm{f}$ ), the levels are very low.

In the summer of 2015, Fig. 2 shows how, when the dammed capacity was at $400 \mathrm{hm}^{3}$ (the legal non-transferable lower limit of today), the water surface was more than $1 \mathrm{~km}$ away from the traditional beaches (Fig. 2d), with the boats concentrated in the small flooded areas (Fig. 2c), completely disconnected from the rest of the reservoir, in clear contrast to the images of the San Juan Reservoir (see Vivir Viajando, 2015) Surcando). The photograph from the summer of 2017 (Fig. 2, images e \& f) shows that the water surface corresponding to 


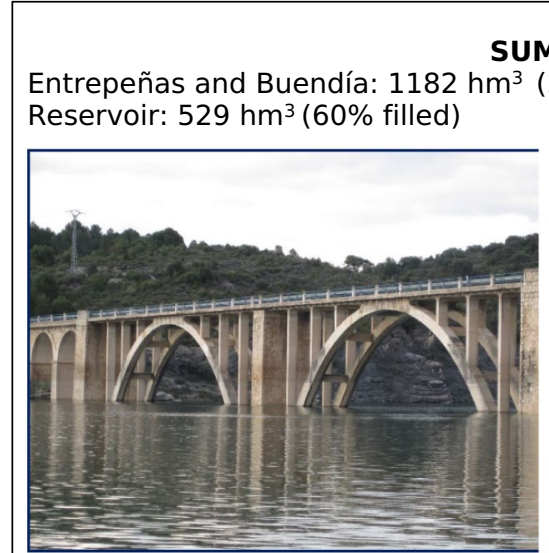

a) Entrepeñas Reservoir, Durón bridge.

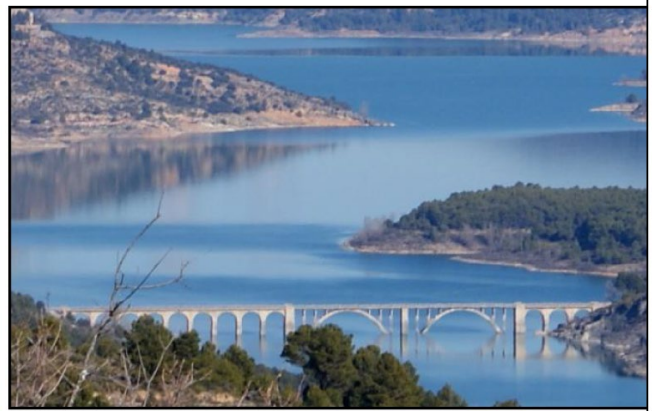

b) Entrepeñas from the viewing point of Alocén.

\section{SUMMER 2015}

Entrepeñas and Buendía: 439 hm³ (20\% combined fill); Entrepeñas Reservoir:140 $\mathrm{hm}^{3}$ ( $17 \%$ filled)

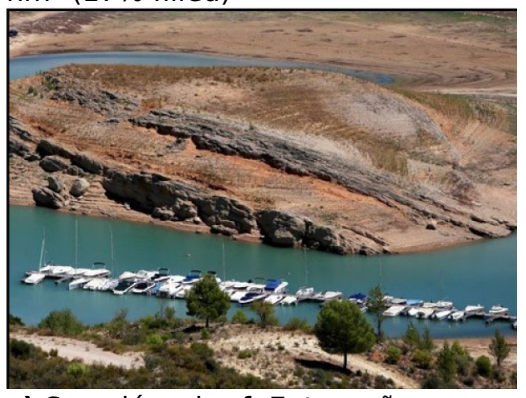

c) Sacedón wharf, Entrepeñas.

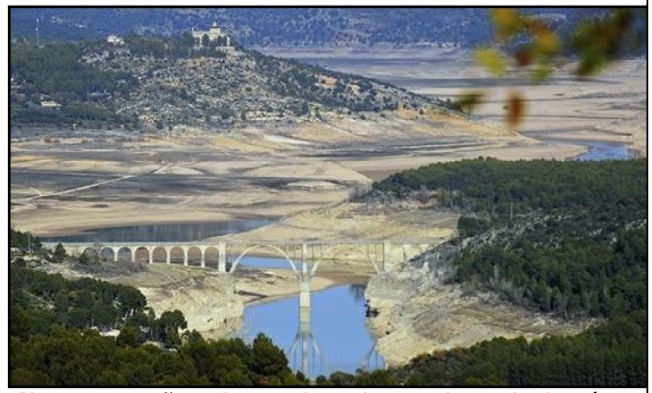

d) Entrepeñas from the viewpoint of Alocén.

\section{SUMMER 2017}

Entrepeñas and Buendía: $240 \mathrm{hm}^{3}$ (9\% combined inflow); Entrepeñas Reservoir: $100 \mathrm{hm}^{3}$ (12\% filled)

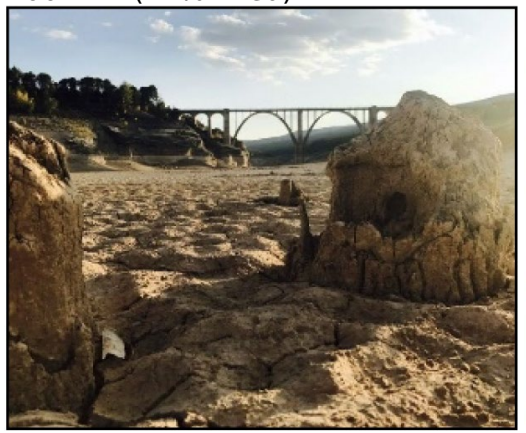

e) Durón bridge.

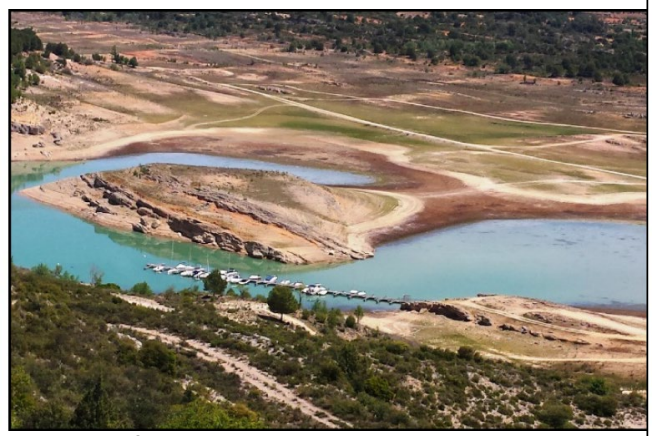

f) Sacedón wharf, Entrepeñas.

Fig. 2 Entrepeñas and Buendía with different water levels (1000, 400 and $240 \mathrm{hm}^{3}$ ). Source: a) Mapio (2010); b) Verpueblos (2010); c) El País (2015); d) Río Tajo Vivo (2015); e) Cuencanews (2017); f) Río Tajo Vivo (2017 


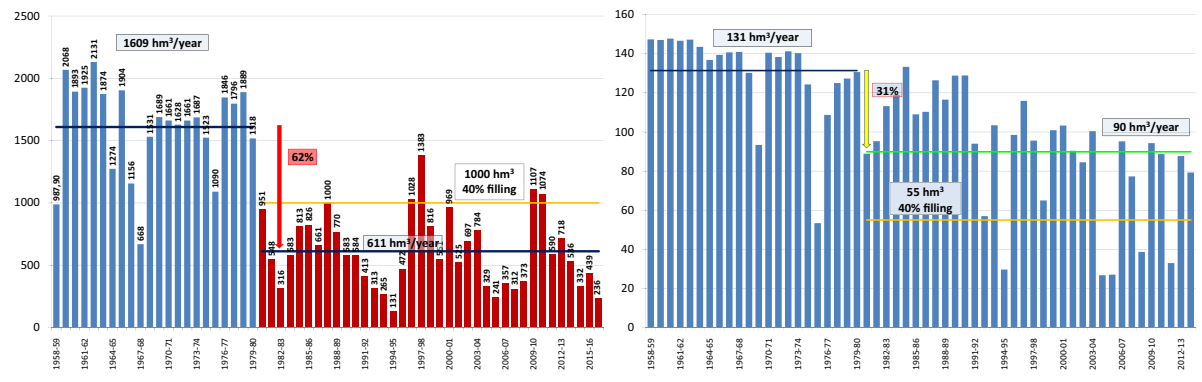

Fig. 3 Evolution of volumes collected in the E\&B Reservoirs (left) and in the San Juan Reservoir (right) Source: Sánchez-Pérez (2018) (left) and compiled by the authors (right)

a dammed volume of $240 \mathrm{hm}^{3}$ was extremely diminished and imposed a significant limitation on the navigable area, which was reduced to less than 5 linear $\mathrm{km}^{3}$

Unfortunately, the establishment of a minimum reservoir line below which water cannot be transferred does not mean that the remaining surface water will be maintained in the reservoirs to enable leisure and recreational uses. In fact, from these volumes, the uses and demands of the Tagus Basin itself must be met, which inevitably means that the dammed levels continue to decrease. Apart from rainy periods, such low water levels in the reservoirs present a desolate landscape that has become the norm since the TST began operating, especially in summer during the popular tourism season.

The reason why this scenario has been recurring since the TST began operating is primarily due to how the E\&B Reservoirs are managed. The transfer of water by the TST must follow certain rules to divert water depending on inflow levels and the amount of water stored. ${ }^{4}$ From more to less water, level 1 is a normal situation and level 2 a pre-alert of a low water level. At both levels, it is assumed that there is surplus water that is transferable. Levels 3 (exceptional hydrological situation) and 4 (emergency) are officially associated with drought situations but instead reflect the situation of the reservoirs as a consequence of the transferred volumes, not of the inflow received (Acuademia 2017b). It seems clear that diversion rules require the transfer of water above the average inflow, which forces the system to operate systematically in a situation of hydrological exceptionality (level 3) or emergency (level 4), regardless of the climatic conditions of a particular hydrological year.

RD 773/2014 (BOE 2014) established the so-called "reference discharges" at $365 \mathrm{hm}^{3} /$ year. This is the maximum amount of water that can be discharged into the Tagus River from its head reservoirs to satisfy the needs of its own basin, thus limiting the needs of the donor basin to that amount. In most years, this value is less than the transferred volume. According to the data of Larraz et al. (2020), since the entry into force of this RD in October 2014 , in $60 \%$ of the months, the volumes stored in E\&B have remained at level 3, that is, in an exceptional hydrological situation. Additionally, the volume stored in the reservoirs has remained below $400 \mathrm{hm}^{3}$ during $16 \%$ of the months since the approval of the RD, at various times nearing the limit of exploitation or the "dead reservoir" level. A reservoir

\footnotetext{
3 In Acuademia (2017a) a more comprehensive analysis of volumes and water surfaces of the Entrepeñas reservoir is made.

4 A complete analysis of the diversion rules can be seen in Larraz et al. (2020).
} 
below $40 \%$ of its full capacity in most years (Fig. 3, left) is incompatible with sustainable economic development through the recreational use of reservoirs.

Therefore, the onset of the TST in 1978 and the approval of the regulations derived from the Tagus Memorandum in 2013-2014 have had clear impacts on the filling level of E\&B and on the water surface area. Consequently, they have significantly harmed the sport and recreational uses of the reservoirs and the tourism development potential of the surrounding municipalities.

\subsection{San Juan Reservoir: Construction, Exploitation and Uses}

The management of the San Juan Reservoir meets multiple objectives: to supply the Tagus riverside cities of Talavera de la Reina and Toledo, the Canal de Isabel II (the main water company in the Madrid region), and various irrigated areas in the Alberche River. The reservoir is also responsible for hydroelectric production and recreational uses, which have led to an important urban, tourism and socioeconomic development of adjacent municipalities. It is, in fact, the only reservoir in the Community of Madrid where bathing and motor sailing are allowed. The management of this reservoir, in which the average filling volumes since 1980 have decreased by slightly less than the average decrease in inflow $(31.6 \%$ compared to $35.5 \%$, see Table 1), shows the management of the reservoir tries to maintain a certain amount of water to favour hydroelectric production but also to support sport and recreational uses. In fact, the filling volumes remained above $60 \%$ during almost the entire series, apart from eight hydrological years, which mostly coincided with periods of severe drought. Significant reserve decreases have also been detected during the main periods of drought, but these have been limited to specific hydrological years when it was necessary to guarantee reservoir-dependent supplies, with levels recovering rapidly thereafter.

Table 1 shows a comparison of the evolution of the variability of water stored and inflows in E\&B and San Juan in the periods analysed (pre- and post-1980). At San Juan, as mentioned above, the decrease in the average inflow led to a slightly smaller decrease in the average stored volumes (35\% vs. 31\%), while at E\&B, this relationship was the opposite: the decrease in stored water was greater than the decrease in inflow (62\% vs. 50\%). Regarding the variability, the data showed that while in E\&B the increase in the variability of the stored volumes was almost ten times higher than the variability of the inflow $(110 \%$ vs. $12 \%$ ), in San Juan it was only one and a half times (102\% vs. $69 \%$ ). In other words, the management of the San Juan Reservoir mitigates the increase in inflow variability compared to $\mathrm{E} \& \mathrm{~B}$, where its management amplifies the variability.

Therefore, this different evolution of the filling levels of E\&B and San Juan is a reflection of different priorities and management decisions. In the case of the headwater reservoirs of the Tagus, since the onset of the TST, the objective has been to maximize the transfers to the Segura Basin, systematically ignoring the prioritized needs of the municipalities of $\mathrm{E} \& \mathrm{~B}$ and of the Tagus Basin in general. These needs include both the maintenance of water surface area in the E\&B Reservoirs, enough in terms of extension and stability for recreational uses, and the establishment of a regime of ecological flows in the river that are adequate in quantity and seasonal variation to fulfil its environmental functions. In the case of the San Juan Reservoir, priority has been given to hydroelectric interests conditioned by the electricity market, seeking high water levels and turnover in summer when electricity prices are higher. These objectives also favour the development of leisure activities linked to the water in the reservoir. Thus, even though there are large cities (Madrid, Toledo, Talavera de la Reina) that rely on the reservoir to guarantee their water supply, the reservoir 


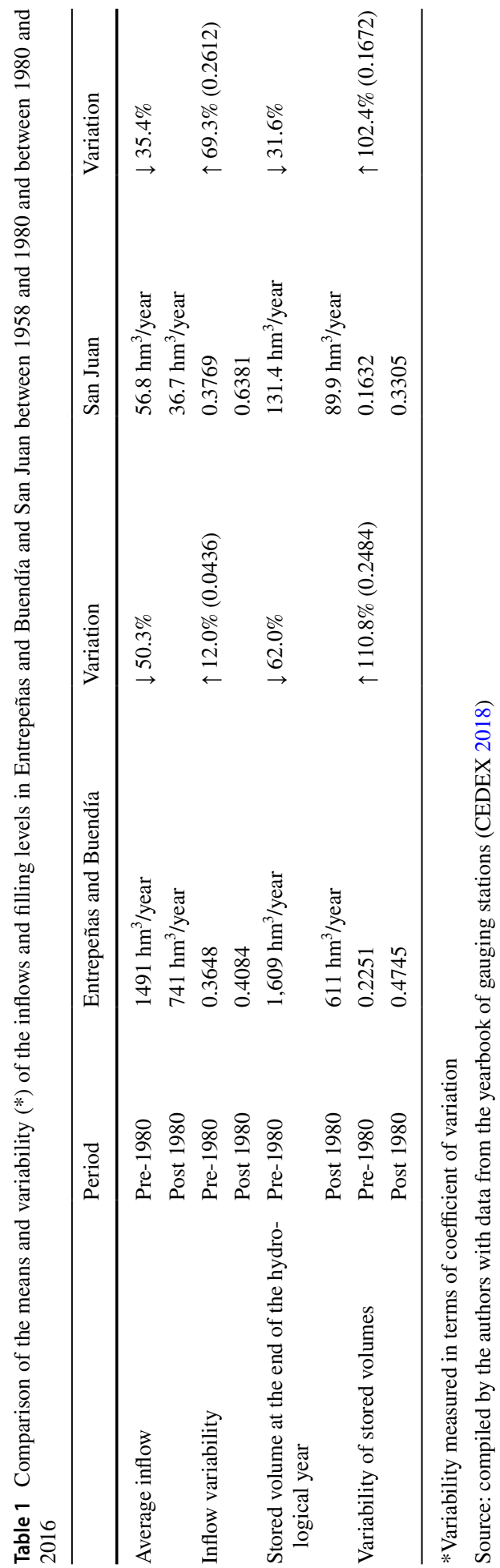


levels have been maintained. This ensures the viability of the tourist and recreational activities around the reservoir, with subsequent population and socioeconomic results that are clearly different from those of E\&B. These differences are discussed further in Sect. 6.

\section{Demographics in E\&B Riverside Municipalities: Comparison with the Situation of the Riverside Municipalities of the San Juan area}

\subsection{Population Evolution in the Riverside Municipalities of E\&B}

In general terms, a significant population decline has occurred since 1950 (the year in which the series was highest) in the provinces of Cuenca and Guadalajara, and this decline coincided with the rural exodus to the cities. Specifically, in the province of Cuenca between 1950 and 2020, the population decreased by $41.6 \%$ compared to a population increase of $119.9 \%$ in the Cuenca capital, with rural municipalities showing a population decline of $66.2 \%$.

In the case of the province of Guadalajara, in the period 1950-2020, the provincial population increased by $28.9 \%$ as a result of growth in the population of the capital by $357.9 \%$, and it was accompanied by a decrease of $53.8 \%$ in the population of the rural municipalities. Between 1950 and 1991, the provincial population in Guadalajara decreased by $26.7 \%$, with rural municipalities declining in population by $67.8 \%$. However, from the late 1990 s onwards, the trend was reversed, with strong population growth concentrated in the capital, and in the Henares Corridor, the industrial and logistic area between Guadalajara and Madrid that is very well connected by road and rail.

The E\&B municipalities suffered a significant and continuous population decline in the 1950-2020 period, with a cumulative decrease of $62.1 \%$. However, this evolution has not been constant, and it must be analysed in relation to two milestones. The first is the construction of the large E\&B Reservoirs, with the flooding of farmland and a triggered change in the economic model based on the development of tourism linked to what is known as Mar de Castilla. This economic change generated new job opportunities in the medium and long term in the tertiary sector. The second milestone was the TST. It started operating in 1981 following a trial period, transferring water from the headwater reservoirs of E\&B towards the Segura Basin in Southeast Spain. This transfer resulted in a significant decrease in the water stored in the reservoirs on numerous occasions (e.g., early 1980s, 1991-1996, 2004-2009, and 2013-2017) to levels where the practice of water sports became very difficult and the aesthetic appeal of the area and other tourist attractions were affected. As a result, the possibilities of socioeconomic development linked to tourism in the area were substantially reduced.

To analyse this temporal evolution in the geographic and socioeconomic context in which the E\&B municipalities are framed, Fig. 5 (right) presents a comparative analysis of the variation rates of the population in these municipalities against those of rural Cuenca and Guadalajara. Thus, after the construction of the headwater reservoirs and just before the TST began operating (1960-1981), the rural exodus from the E\&B area (with a population decline of $38.7 \%$ ) was less severe than that from the rural municipalities of the provinces of Cuenca and Guadalajara (-38.7 vs. $-51.9 \%)$. This difference may be due to the development of job opportunities in the tourism sector, e.g., real estate developments linked to reservoirs, opening of tourist attractions, and leisure and recreational businesses. 
Table 2 Population variation rates in the riverside municipalities of E\&B and San Juan and overall in rural Cuenca and Guadalajara and in the Sierra Oeste of Madrid

\begin{tabular}{llllll}
\hline Period & & E\&B & $\begin{array}{l}\text { Rural Cuenca and } \\
\text { Guadalajara }\end{array}$ & San Juan & Sierra Oeste \\
\hline Pre-transfer & $1960-1981$ & $-38.7 \%$ & $-51.9 \%$ & $+22.7 \%$ & $-5.4 \%$ \\
Post-transfer & $1981-2020$ & $-27.1 \%$ & $-10.5 \%$ & $+108.8 \%$ & $+144.0 \%$ \\
& $1981-2011$ & $-9.0 \%$ & $+0.9 \%$ & $+97.7 \%$ & $+124.5 \%$ \\
& $2011-2020$ & $-19.9 \%$ & $-11.3 \%$ & $+5.7 \%$ & $+8.7 \%$ \\
\hline
\end{tabular}

Source: compiled by authors using data from the INE (2020)

It can be said that the E\&B Reservoirs were able to attenuate the vertiginous rural exodus that existed in the rest of the rural areas of the province.

However, since the transfer has been operating (1981-2020), the overall population of the E\&B municipalities has decreased by $27.1 \%$, almost three times more than the population decrease of the rural municipalities of both provinces $(10.5 \%)$. At the time of a rural exodus in the area, the E\&B municipalities were able to more effectively resist the departure of their population to cities by offering new development opportunities; however, since the beginning of the TST, the overall population of their municipalities has decreased each year to a greater extent than that of the other rural municipalities in the province.

In fact, in the period 1981-2011 (Table 2), the municipalities of rural Cuenca and Guadalajara even showed a slight increase in population of $1 \%$, while in the area of the reservoirs, the population decreased by $9 \%$. Between 2011 and 2020, the overall population of the $\mathrm{E} \& \mathrm{~B}$ municipalities has continued to decline faster $(-19.9 \%)$ than that of their rural neighbours $(-11.3 \%)$, in what appears to be a continuous process of depopulation caused by a lack of development of the tourism potential in the area.

This lack of interest in taking advantage of the territory's potential to support its socioeconomic development is evidenced when the situation is compared with that of the municipalities of the San Juan Reservoir. The maintenance of a higher filling level and a management approach that also protects the reservoir's sport and recreational uses have allowed tourism to become important with the consequent population and socioeconomic developments. This result is discussed further in the next section.

\subsection{Population Evolution in the Riverside Municipalities of the San Juan Reservoir}

To study the population dynamics around the San Juan Reservoir, the adjacent municipalities of San Martín de Valdeiglesias and Pelayos de la Presa were selected. As in the case of the municipalities of E\&B, their population evolution was compared with that of the Sierra Oeste region of Madrid to which they belong.

The two bordering municipalities of the San Juan Reservoir did not experience the rural exodus to large cities that their neighbouring municipalities did; in contrast, since 1960, they have actually seen their populations continuously increase. In fact, from 1960 to 1981 , the population of the towns of the Sierra Oeste of Madrid decreased by 5.4\%, while the population of San Martín de Valdeiglesias and Pelayos de la Presa increased by $22.7 \%$ (see Table 2). It was in this period that the urban development and tourist infrastructures of the municipalities of San Juan began. In other words, while their neighbouring towns still saw 


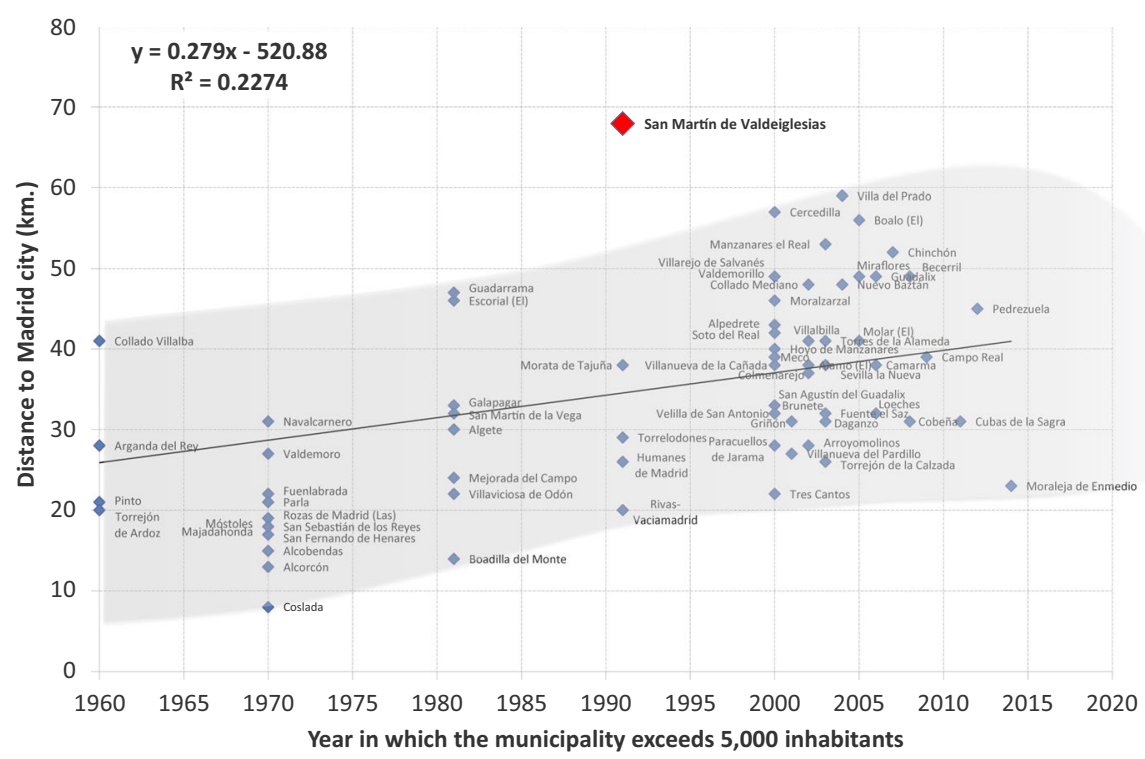

Fig. 4 Distribution of municipalities in the community of Madrid according to their distance from the capital of Madrid and year in which their populations surpassed 5000 inhabitants. Source: compiled by the authors from the INE (2020)

part of their population leave for the cities, the municipalities of the San Juan Reservoir were able to attract more people due to the economic attraction of their reservoir.

From 1981 to the present, the municipalities of San Juan have continued this upward trend, having seen their population doubled in the period 1981-2020. However, 1981 was a turning point in the population evolution of the towns of the Sierra Oeste, which grew almost 35 percentage points more in the same period than the San Juan municipalities (144\% vs. 109\%). However, a careful analysis of the figures shows that the strong growth of the municipalities of the Sierra Oeste region could be explained by the influx from Madrid, since it is more accentuated in those municipalities closer to Madrid, which have seen their populations quadruple (INE 2020).

To clarify the population effect of the San Juan Reservoir on the adjacent municipalities, the moment in which the municipalities of the Madrid region passed the threshold that was used to define a municipality as urban (5000 inhabitants) was analysed together with their distance from the city of Madrid. The effect was manifested in sequential population growth depending on the distance a town was from the capital city. Figure 4 shows that, on average, the closest municipalities were the first to pass the 5000 inhabitant limit, a limit that has been extending further away from Madrid. However, San Martín de Valdeiglesias is the only municipality of Madrid that is more than $60 \mathrm{~km}$ from the capital of Madrid, which has more than 5000 inhabitants. Similarly, of the municipalities that became urban before 1991, San Martín de Valdeiglesias was by far the farthest from the capital. The linear regression analysis, $y=0.2790 x-520.8828$, shows us the linear relation between the distance to which the municipality is located and the year in which it exceeded the 5000 

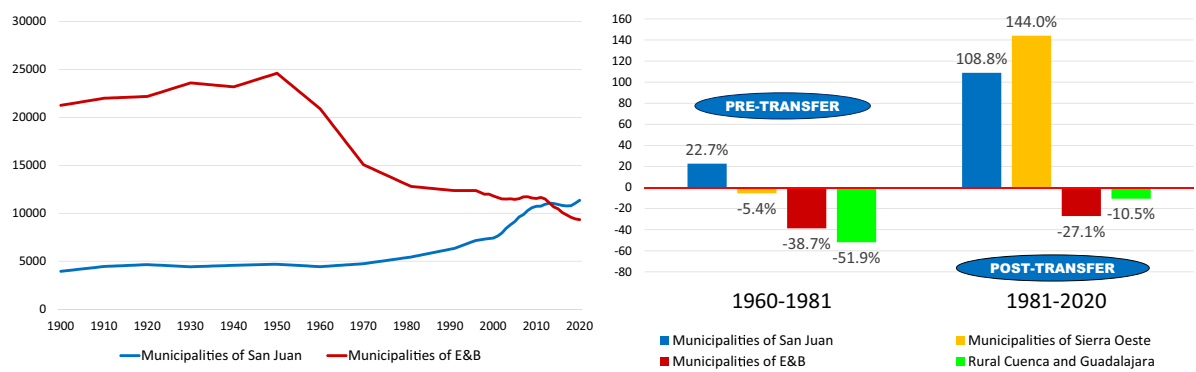

Fig. 5 Evolution of the population in the riverside municipalities of the San Juan Reservoir in comparison with the riverside municipalities of E\&B (1900-2020) (left) and comparison of population variation rates in the municipalities of E\&B, rural Cuenca and Guadalajara, San Juan Reservoir and Sierra Oeste of Madrid in the pre- (1960-1981) and post-transfer (1981-2020) periods (right). Source: compiled by the authors using data from the INE (2020)

inhabitant barrier. ${ }^{5}$ It follows that 1991 corresponds to an estimate of $34.3 \mathrm{~km}$; that is, the municipalities that were at that distance from the capital of Madrid should have passed the 5000 inhabitant barrier that year. However, San Martín de Valdeiglesias passed that barrier that year even though it was at twice the distance. In fact, in statistical terms, it can be considered an outlier since it clearly exceeded the mean distance plus three times the standard deviation. Therefore, it seems difficult to attribute this growth due to distance to the city of Madrid; rather, the growth may be due to the socioeconomic development linked to the recreational uses of the San Juan Reservoir.

Having ruled out the capital city effect on the growth of this municipality, a comparison was made between the population evolution of two municipalities that enjoyed clear tourism development due to the recreational uses of the San Juan Reservoir and that of the E\&B municipalities. Figure 5 (left) shows that while the former has experienced annual growth every year since 1960 (except between 2014 and 2016), the municipalities of E\&B overall have seen their population decline each year starting from the beginning of the construction of the E\&B Reservoirs in the late 1940s.

However, as seen in the previous section, a more detailed analysis of the data identified temporal and geographic differences in the series. Figure 5 (right) seems to indicate that the construction of the E\&B Reservoirs in the headwaters of the Tagus and that of San Juan in the Alberche River managed to halt the rural exodus occurring in the early second half of the twentieth century in the rural municipalities around them, even leading to a population increase of $22.68 \%$ in the municipalities of San Juan.

However, since 1981, when the TST started, the E\&B municipalities have experienced population loss rates that are higher than those of the rural municipalities of Cuenca and Guadalajara, which is in contrast to the results of the previous period. In other words, the mitigating effect of the opportunities offered by the existence of the reservoirs seems to have vanished. In contrast, the municipalities of San Juan continue to enjoy the opportunities for socioeconomic development provided by recreational uses linked to a reservoir with a more stable water surface area. Overall, the population doubled during that period,

\footnotetext{
5 The coefficient of determination is 0.2274 , which can be increased to 0.3733 through a grade 6 potential regression with the same conclusions, so for ease of understanding, the linear regression is shown.
} 
although, as mentioned earlier, the growth rate was lower than the average growth rate of the municipalities of the Sierra Oeste region due to the strong population growth of the municipalities closest to Madrid.

\section{Conclusions}

This article, through demographic analysis, highlights the potential socioeconomic implications of different ways of managing hydraulic infrastructures. An existing reservoir can be a tourist attraction in rural areas, offering leisure and recreational activities that can lead to socioeconomic development. However, the materialization of these expectations is conditioned by the management of the reservoirs. If such management considers the needs of the adjacent populations, rural development strategies can be articulated to maximize the potential benefits linked to the existence of these infrastructures.

However, if these needs are ignored or if management completely prioritizes the demands of the other regions, the bordering populations will continue to suffer only the negative impacts of their presence. A paradigmatic case is that of the municipalities of the E\&B Reservoirs, which were analysed in this article. Their best farmland was forfeited under the waters of the reservoirs in the 1950s. Then, in the 1960s and 1970s, benefitting from their proximity to Madrid, they experienced economic development linked to the recreational use of the reservoirs. However, the onset of the TST in 1981 truncated the development expectations. An analysis of the population data makes the future look bleak. These municipalities have seen their population decline by almost half since the 1950s.

The onset of the TST is a relevant date in the process of depopulation. In the period prior to the start of the TST, the population exodus in the riverside municipalities of E\&B was less than that in the surrounding rural municipalities, suggesting a possible mitigating effect as a consequence of the potential socioeconomic development associated with the recreational uses of the reservoirs. Once the TST started, these municipalities lost their population at a higher rate than that of the comparable municipalities of the provinces to which they belong, referred to in this article as rural Cuenca and Guadalajara.

The population evolution of the E\&B municipalities was especially striking when compared with that of the municipalities of the San Juan Reservoir, which has similar characteristics but whose reservoir is managed with other priorities. The population of the municipalities of San Juan has doubled since 1950, largely due to tourism development, highlighting the potential of the reservoirs to favour socioeconomic development if they are managed to consider tourism, sport and recreational economic potential.

Management of the San Juan Reservoir, facilitating the development of these activities, provides an important point of contrast with how reservoirs at the Tagus headwaters have been managed. The E\&B Reservoirs have a maximum water capacity that is 17 times greater than that of San Juan, but recreational uses and the socioeconomic development opportunities associated with them are systematically ignored by water management because of the undue prioritization of the TST.

The San Juan Reservoir is a good example of what would be possible for E\&B in terms of promoting socioeconomic development linked to the sustainable use of the recreational potential of reservoirs. Infrastructure management models that allow bordering populations to articulate territorial development models based on the landscape, environmental and cultural values of their territories must be encouraged. It must not be forgotten that water for in-basin development precedes out-basin demands. 
In the study carried out in the Duero Basin, also in Spain, during the period (from 1980) of decreasing inflows, Morán-Tejada et al. (2012) concluded that for many reservoirs, particularly those used for hydropower production, the storage increased, meaning a dominance of other interests over environmental concerns in terms of reservoir management. In addition to this other Spanish basin, in the Tagus Basin, we state that the management of the E\&B Reservoirs is being carried out without considering the socioeconomic aspects of the riverside municipalities.

Moreover, in the context of climate change that was included, following Garrote (2017), the effects of climate change on water resources can be very significant (which would only worsen the situation in $\mathrm{E} \& \mathrm{~B}$ ), but the effects of public policy for water resource management can be comparatively much greater. In his opinion, there is potential to guide rational long-term climate change adaptation in the sector in such a way that, in addition to offsetting its effects, it may even substantially improve the current reality. Water management based on the socioeconomic development of reservoir banks is necessary.

Authors Contributions Conceptualization, B. Larraz and E. San-Martin; methodology, B. Larraz and E. San-Martin; software, B. Larraz; validation, B. Larraz; formal analysis, B. Larraz and E. San-Martin; investigation, B. Larraz and E. San-Martin; resources, B. Larraz and E. San-Martin; data curation, B. Larraz; writing — original draft preparation, B. Larraz; writing—review and editing, B. Larraz and E. San-Martin; supervision, E. San-Martin; project administration, B. Larraz; funding acquisition, B. Larraz and E. SanMartin. All authors have read and agreed to the published version of the manuscript.

Funding Open Access funding provided thanks to the CRUE-CSIC agreement with Springer Nature. This study has been partially supported by the Association of Municipalities of Entrepeñas and Buendía.

Availability of Data and Material All data come from official sources.

Code Availability (Software Application or Custom Code) Not applicable.

\section{Declarations}

Conflicts of interest Not applicable.

Open Access This article is licensed under a Creative Commons Attribution 4.0 International License, which permits use, sharing, adaptation, distribution and reproduction in any medium or format, as long as you give appropriate credit to the original author(s) and the source, provide a link to the Creative Commons licence, and indicate if changes were made. The images or other third party material in this article are included in the article's Creative Commons licence, unless indicated otherwise in a credit line to the material. If material is not included in the article's Creative Commons licence and your intended use is not permitted by statutory regulation or exceeds the permitted use, you will need to obtain permission directly from the copyright holder. To view a copy of this licence, visit http://creativecommons.org/licenses/by/4.0/.

\section{References}

Acuademia (2017a, March 8). ¿Cómo estaría Entrepeñas si ...? [Blog post]. Retrieved from https://www. acuademia.com/2017/03/como-estaria-entrepenas-si/. Accessed 10 Aug 2021

Acuademia (2017b, August 14). De la sequía y el estado de Entrepeñas y Buendía. [Blog post]. Retrieved from https://www.acuademia.com/2017/08/de-la-sequia-y-el-estado-de-entrepenas-y-buendia/. Accessed 7 Feb 2020

BOE (1971) Ley 21/1971, de 19 de junio, sobre el aprovechamiento conjunto Tajo-Segura. Boletín Oficial Del Estado 148:10115-10116 
BOE (1980) Ley 52/1980, de 16 de octubre, de Regulación del Régimen Económico de la Explotación del Acueducto Tajo-Segura. Boletín Oficial Del Estado 256:23702-23704

BOE (2001) Ley 10/2001, de 5 de julio, del Plan Hidrológico Nacional. Boletín Oficial Del Estado 161:1-44

BOE (2013) Ley 21/2013, de 9 de diciembre, de evaluación ambiental. Boletín Oficial Del Estado 296:1-86

BOE (2014) Real Decreto 773/2014, de 12 de septiembre, por el que se aprueban diversas normas reguladoras del trasvase por el acueducto Tajo-Segura. Boletín Oficial Del Estado 223:71634-71639

BOE (2015) Ley 21/2015 de 20 de julio, por la que se modifica la Ley 43/2003, de 21 de noviembre, de Montes, 173, pp 60234-60272

Böhme K, Hanell T, Pflanz K, Zillmer S, Niemi P (2009) The ESPON Pro-gramme. Interim Report, ESPON \& Spatial Foresight

Burillo MP, Burillo F, Ruiz E (2013) Serranía Celtibérica (España). Un proyecto de Desarrollo Rural para la Laponia del Mediterráneo. Zaragoza, Spain: Instituto Celtiberia de Investigación y Desarrollo Rural Ed

Burillo-Mozota F (2011) Oppida y Ciudades Estado Celtibéricos. Complutum 22(2):277-295

Cabezas F (2013, December) El sistema de Cabecera del Tajo y el trasvase Tajo-Segura. Soporte técnico al Real Decreto 773/2014. https://www.miteco.gob.es/images/es/Anexo\%20tecnico\%20ATS_tcm30136922.pdf. Accessed 3 Oct 2020

CEDEX (2018) Anuario de Aforos. Retrieved from: https://ceh.cedex.es/anuarioaforos/default.asp. Accessed 7 Feb 2019

Cerdà P (2017) Los últimos. Voces de la Laponia española. Logroño, Spain: Pepitas de Calabaza Ed

CHT (1998) Plan Hidrológico de la Cuenca del Tajo. Ministerio de Medio Ambiente-Confederación Hidrográfica del Tajo, Madrid. Retrieved from http://www.chtajo.es/LaCuenca/Planes/PlanHidrologico/ OtrosDoc/Documents/A31958-31994.pdf. Accessed 3 Oct 2020

CHT (2015) Plan hidrológico de la parte española de la demarcación hidrográfica del tajo (ciclo de planificación 2015-2021), Ministerio de Agricultura, Alimentación y Medio Ambiente-Confederación Hidrográfica del Tajo. http://www.chtajo.es/LaCuenca/Planes/PlanHidrologico/Planif_2015-2021/ Paginas/Plan_2015-2021.aspx. Accessed 3 Oct 2020

Collantes F, Pinilla V (2011) Peaceful surrender: the Depopulation of rural Spain in the twentieth century. Cambridge Scholar Publishers, Newcastle Upon Tyne

Collantes F, Pinilla V, Sáez LA, Silvestre J (2014) Reducing Depopulation in rural Spain: the impact of immigration. Popul Space Place 20:606-621. https://doi.org/10.1002/psp.1797

Cuencanews (2017, October, 2). Para el PSOE Castilla-La Mancha "el Tajo se muere y el PP lo está matando". https://goo.gl/U4mufZ. Accessed 5 Oct 2017

De Lucas A (2019) Concepto, análisis histórico y determinación de excedentes de la cuenca del Tajo. Aplicación al trasvase Tajo-Segura, PhD Thesis, Universidad de Alcalá de Henares, Madrid.

Del Molino S (2016) La España vacía. Viaje por un país que nunca fue. Madrid, Spain: Turner Ed

Duda-Gromada K, Bujdosó Z, David L (2010) Lakes, reservoirs and regional development through some examples in Poland and Hungary. In: GeoJournal of tourism and geosites, III, no. 1, vol 5, pp 16-23

El País (2015, August 17). El seco futuro del Mar de Castilla. https://goo.g1/VxAH6u. Accessed 17 Aug 2015

Flores FJ (coord.) (2004) 50 años de la Confederación Hidrográfica del Tajo. Madrid, Spain: Ministerio de Medio Ambiente y Confederación Hidrográfica del Tajo, Eds

Gallego, M.S. (2019). Las sentencias del Tribunal Supremo sobre el incumplimiento por el plan hidrológico del Tajo de 2016 de la regulación sobre caudales ecológicos y objetivos medioambientales. Gabilex Revista del Gabinete Jurídico de Castilla-La Mancha 18:15-46

García Docampo M (2016) Recent residential mobility in Spain. Mediterranean Journal of Social Sciences, 7(3)S1:192-200. https://doi.org/10.5901/mjss.2016.v7n3s1p192

Garrote L (2017) Managing water resources to adapt to climate change: facing uncertainty and scarcity in a changing context. Water Resour Manage 31:2951-2963

Hall CM, Härkönen T (2006) Lake tourism: an integrated approach to lacustrine tourism system. Channel View Publications, Clevedon

Hernández-Mora N (2013) Presentación in Baeza Sanz. D. et al. (Eds.). El Tajo. Historia de un río ignorado, Fundación Nueva Cultura del Agua, 13-22

Hernández-Mora N, del Moral L (2015) Developing markets for water reallocation: Revisiting the experience of Spanish water mercantilización. Geoforum 62:143-155

INE (2020). Inebase. Retrieved from http://www.ine.es/dyngs/INEbase/listaoperaciones.htm

Jiménez Aparicio B (1947) Los pantanos de Entrepeñas y Buendía y su túnel de enlace. Revista De Obras Públicas 2782:57-67

Larraz B, San Martín E, Baeza D., Sánchez MA (2020) Propuesta AMREEB de mejora de las Reglas de Explotación del trasvase Tajo-Segura, Grupo de Investigación del Tajo (Grupo de Investigación de 
Ciencias de la Tierra y del Espacio), UCLM. http://blog.uclm.es/grupotajo/propuesta-del-grupo-deinvestigacion-a-peticion-de-amreeb/. Accessed 20 Jun 2020

Lobanova A, Liersch S, Tàbara JD, Koch H, Hattermann FF, Krysanova V (2017) Harmonizing humanhydrological system under climate change: a scenario-based approach for the case of the headwaters of the Tagus River. J Hydrol 548:436-447

Lorenzo-Lacruz J, Vicente-Serrano SM, López-Moreno JI, Beguería S, García-Ruiz JM, Cuadrat JM (2010) The impact of droughts and water management on various hydrological systems in the headwaters of the Tagus River (central Spain). J Hydrol 386(1-4):13-26

Mapio (2010). Tarde de abril de 2010. Retrieved from http://mapio.net/pic/p-34805500/

MARM (2009). Población y Sociedad Rural. Análisis y Prospectiva - Serie AgrInfo nº12. Subdirección General de Análisis, Prospectiva y Coordinación, Subsecretaría. Madrid, Spain: Ministerio de Medio Ambiente y Medio Rural y Marino, Ed

Molina A, Melgarejo J (2016) Water policy in Spain: seeking a balance between transfers, desalination and wastewater reuse. Int J Water Resour Dev 32(5):781-798

Morán-Tejeda E, Lorenzo-Lacruz J, López-Moreno JI, Ceballos-Barbancho A, Zabalza J, Vicente-Serrano SM (2012) Reservoir management in the Duero Basin (Spain): impact on river regimes and the response to environmental change. Water Resour Manage 26:2125-2146

Moreno MA (2018) SOS Despoblación. Ciudad Nueva, sept-2018. Retrieved from https://www.ciudadnueva. com/articulo.php?articulo=2800. Accessed 23 Nov 2020

Morote AF, Olcina J, Rico AM (2017) Challenges and proposals for socio-ecological sustainability of the tagus-segura aqueduct (Spain) under Climate Change. Sustainability 9(11):2058

Otiang'a-Owiti GE, Oswe IA (2007) Human impact on lake ecosystems: the case of Lake Naivasha, Kenya. Afr J Aquat Sci 32:79-88

Pinilla V, Saez LA (2017) Rural Depopulation in Spain: Genesis of a problem and innovative policies. Centre for Studies on Depopulation and Development of Rural Areas (CEDDAR) Report, 2017-2

Pittock J, Meng J, Geiger M (2009) Interbasin water transfers and water scarcity in a changing world - a solution or a pipedream? A discussion paper for a burning issue. WWF Germany. 61 p.

Rey D, Garrido A, Calatrava J (2016) An innovative option contract for allocating water in inter-basin transfers: the case of the Tagus-Segura transfer in Spain. Water Resour Manage 30(3):1165-1182

Río Tajo Vivo (2015, December 27). Comparativa demoledora previa y posterior al memorándum del Tajo. Retrieved from https://goo.gl/fF7iZn. Accessed 19 May 2017

Río Tajo Vivo (2017, May 19) La cabecera del río Tajo agoniza: por debajo del umbral mínimo no trasvasable de $368 \mathrm{hm}^{3}$. Retrieved from https://goo.gl/YYbHlc. Accessed 19 May 2017

San Martín E, Larraz B, Gallego MS (2020) When the river does not naturally flow: a case study of unsustainable management in the Tagus River (Spain). Water Int 45(3):189-221

Sánchez Pérez MA (2018) Informe hidrológico sobre la gestión del macroembalse de Entrepeñas y Buendía, Estudio técnico. Retrieved from http://blog.uclm.es/grupotajo/. Accessed 16 Apr 2018

Tikkanen I (2003) Classification of lake tourism activities in Finland: A resource approach. International Lake Tourism Conference, Savonlinna, Finland, University of Kuopio. Retrieved from http://www. taloverkot.fi/irma.tikkanen/tikkanenpaperlaketourism.pdf. Accessed 23 Nov 2020

Verpueblos (2010, July 31). Viaducto sobre la N-204, carretera que va desde Sacedón hasta la N-II (A-2), carretera de Barcelona. Retrieved from https://goo.gl/PNhDtp. Accessed 12 May 2017

Vivir Viajando (2015) Embalse de San Juan. La playa de Madrid, España. Retrieved from https://doshaciendofotos. blogspot.com/2015/07/embalse-de-san-juan-la-playa-de-madrid.html. Accessed 23 June 2021

Yusof N'A, Rahman S, Iranmanesh M (2019) Lake tourism and environmental practices. In: Book: Alternative Tourism. Tanjung Malim, Perak, Malasia: Universiti Pendidikan Sultan Idris Ed

Zoido Naranjo F, Arroyo Pérez A (2003) La Población de España. In: Andrés Arroyo (coord.) Tendencias demográficas durante el siglo XX en España. Madrid, Spain: Instituto Nacional de Estadística Ed

Publisher's Note Springer Nature remains neutral with regard to jurisdictional claims in published maps and institutional affiliations. 